\title{
Design of Switch Operation Mode Rectenna and Analysis Effect of Power Absorbed Rectenna toward Power Received on FM 88-108 MHz Radio
}

\author{
Rudy Yuwono, Hilman Y.R, and Endah Budi.Purnomowati
}

\begin{abstract}
Energy harvesting process can be done in many ways. One of them is by using rectenna. Rectenna is a combination of rectifier and antenna that can convert electromagnetic power into DC output voltage. The use of rectenna will disturb radio device because rectenna will absorb electromagnetic waves around the radio so a switch to adjust the time rectenna will work is necessary. As there is already an exclusive automatic switching method for rectenna and its neighboring device, which is Switch Operation Mode Rectenna, this research will discuss about the design of Switch Operation Mode Rectenna on radio by using $5 \mathrm{~V}$ relay circuit, which functions as a regulator of radio and rectenna. This research also discusses how the effect of rectenna on the power received by FM 88-108 MHz radio.
\end{abstract}

Index Terms-Rectenna, switch, energy harvesting, DC voltage.

\section{INTRODUCTION}

Rectifier antenna (rectenna) can be used for energy harvesting with its antenna serves as the receiver of electromagnetic waves and the rectifier works to convert the electromagnetic wave into DC voltage [1].

The use of rectenna will affect the power received by radio device because rectenna will absorb electromagnetic waves around the radio [2]. Therefore, it is necessary to regulate the time rectenna will work and Switch Operation Mode Rectenna (SOMR) is an exclusive automatic switching method for rectenna and its neighboring device, which, in this case, is a radio (SOMRR) [3]. This switch will activate the rectenna if the radio connected to the switch is off or not working and will deactivate the rectenna if the connected radio is active [4].

\section{RESEARCH MethODOLOGY}

This study used a $5 \mathrm{~V}$ relay circuit to set the switch on the radio and rectenna, two rectennas, a FM 88-108 $\mathrm{MHz}$ radio, and a field strength analyzer tool to measure the power received by radio's antenna and rectenna as objects of analysis [5].

There are five measurements for SOMRR. The first measurement is to measure rectenna's output voltage when it is not connected to SOMRR. The second is to measure

Manuscript received September 12, 2018; revised November 15, 2018.

The authors are with Department of Electrical Engineering, University of Brawijaya J1 MT Haryono 167, Malang, Indonesia (rudy_yuwono@ub.ac.id,endah_budi@ub.ac.id). rectenna's output voltage when it is connected to SOMRR and the radio is off [6]. The third is similar to the second but the radio is on. The fourth is to measure rectenna's output voltage and the power received by radio's antenna when the radio is on [7]. The fifth is similar to the fourth measurement but the radio is on [8].

The first three measurements used one rectenna and a SOMRR. Each of the first three measurements is done three times and the average value is used to compare the three measurements [9].

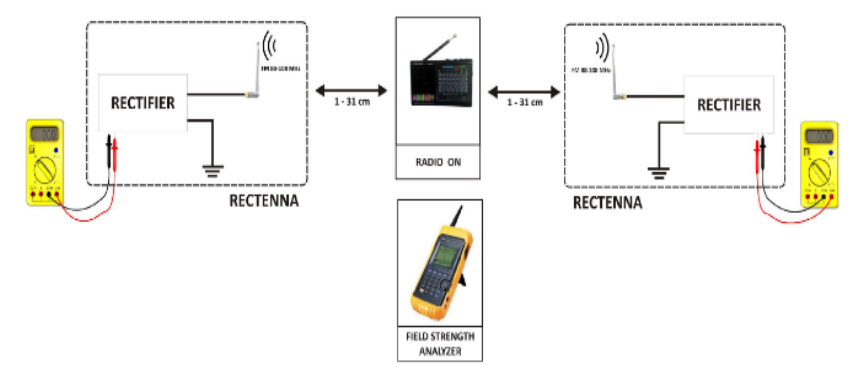

Fig. 1. Arrangement of rectenna's output voltage and SOMRR's received output power measurements when the radio is on.

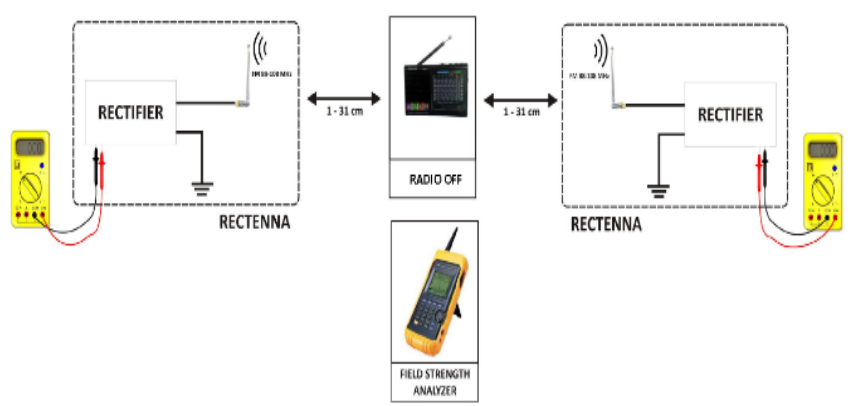

Fig. 2. Arrangement of rectenna's output voltage and SOMRR's received output power measurements when the radio is off.

The fourth and fifth measurement used two rectennas, one on the left of the radio while the other on the right [9]. The two measurements have $1-31 \mathrm{~cm}$ distance variation, and the value is recorded every $3 \mathrm{~cm}$. The arrangement for the fourth measurement can be seen in Fig. 1 while the fifth can be seen in Fig. 2.

\section{RESULT AND ANALYSIS}

\section{A. Rectenna's Output Voltage without SOMRR}

The measurement on rectenna's output voltage when it is not connected to SOMR has an average of $2.201 \mathrm{~V}$. The details can be seen in Table I. 
TABLE I: RECTENNA'S OUTPUT VOLTAGE RESULT WHEN IT IS NOT CONNECTED TO SOMRR

\begin{tabular}{cccc}
\hline \multicolumn{4}{c}{ Rectenna's output voltage $(\mathbf{V})$} \\
\hline $1^{\text {st }}$ test & $2^{\text {nd }}$ test & $3^{\text {rd }}$ test & Average \\
\hline 2.197 & 2.202 & 2.205 & 2.201 \\
\hline
\end{tabular}

B. Rectenna's Output Voltage with SOMRR and Radio is Off

Rectenna's voltage output measurement result when the rectenna is connected to SOMRR and the radio is off has an average of $2.110 \mathrm{~V}$. The details can be seen in Table II.

TABLE II: RECTENNA'S OUTPUT VOLTAGE RESULT WHEN IT IS CONNECTED TO SOMRR AND THE RADIO IS OFF

\begin{tabular}{llll}
\hline \multicolumn{4}{c}{ Rectenna's output voltage (V) } \\
\hline $1^{\text {st }}$ test & $2^{\text {nd }}$ test & $3^{\text {rd }}$ test & Average \\
\hline 2.10 & 2.110 & 2.110 & 2.110 \\
\hline
\end{tabular}

C. Rectenna's Output Voltage with SOMR and Radio is $\mathrm{On}$

Rectenna's output voltage measurement result when the rectenna is connected to SOMR on radio and the radio is on has an average of $0.0337 \mathrm{~V}$. The details can be seen in Table III.

TABLE III: RECTENNA'S OUTPUT VOLTAGE RESULT WHEN IT IS CONNECTED TO SOMR ON RADIO AND THE RADIO IS ON

\begin{tabular}{llcl}
\hline \multicolumn{4}{l}{ Rectenna's output voltage $(\mathbf{V})$} \\
\hline $1^{\text {st }}$ test & $2^{\text {nd }}$ test & $3^{\text {rd }}$ test & Average \\
\hline 0.0300 & 0.0340 & 0.0370 & 0.0337 \\
& & & \\
\hline
\end{tabular}

As seen in Fig. 3, rectenna's output voltage when it is not connected to SOMR does not differ much from when it is connected to SOMR on radio with the radio being off. However, rectenna's output voltage when it is connected to SOMR on radio and the radio is on is very different from the other two measurement results with the value being very close to zero.

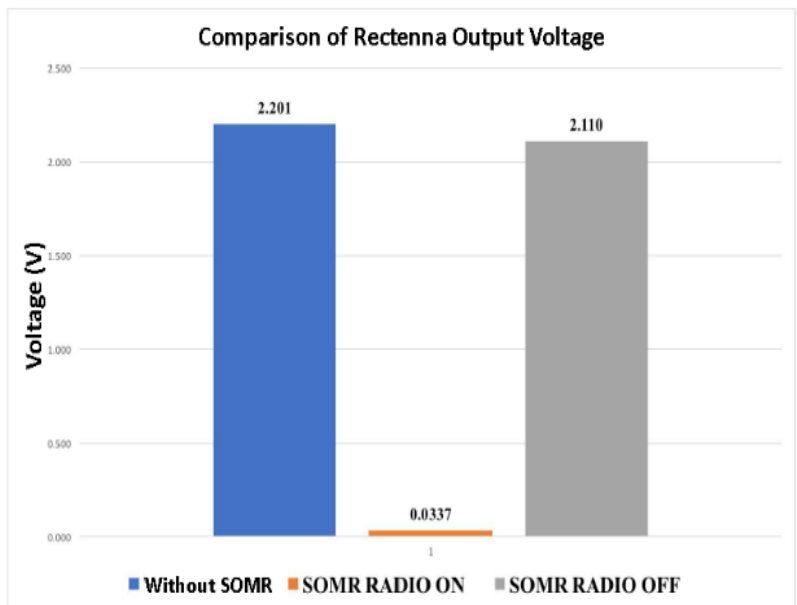

Fig. 3. Comparison of rectenna's output voltage during the first three measurements.

\section{Rectenna's Output Voltage and SOMRR's Received} Output Power When the Radio is on with Distance Variation

Fig. 4 shows rectenna's output voltage when the radio is on according to the distance from the radio, which do not have significant difference in value despite the distance. The right rectenna has 2.253 voltage as its highest output, which is obtained at $4 \mathrm{~cm}$ distance, while the left rectanna has 2.224 voltage as its highest output, which is obtained at 4 $\mathrm{cm}$ distance [10].

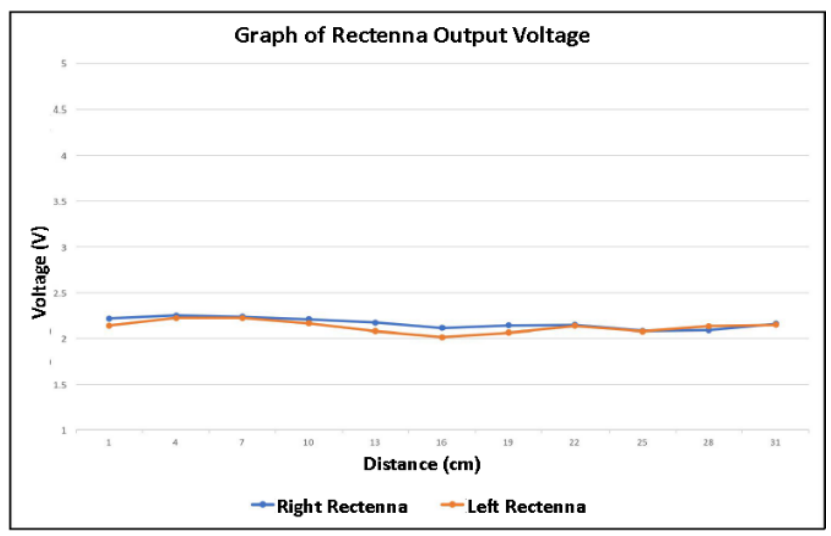

Fig. 4. Rectenna's output voltage when the radio is on

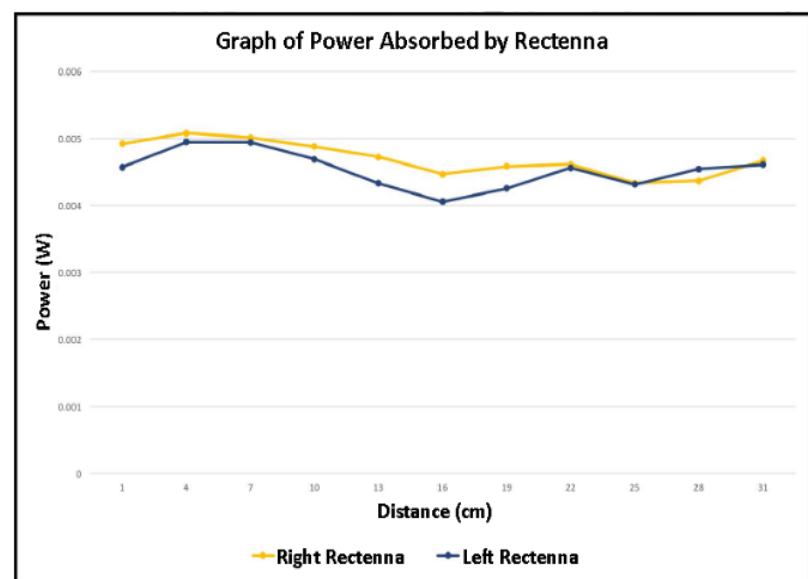

Fig. 5. Rectenna's power calculation result.

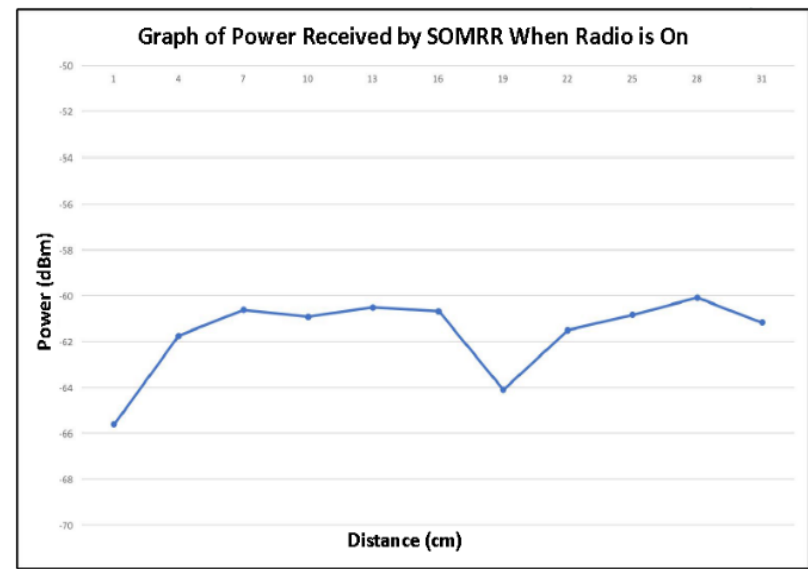

Fig. 6. SOMRR's received power when the radio is on.

For the power calculation, the rectenna is connected to a resistor with $1 \mathrm{k} \Omega$ resistance, and the calculation result can be seen in Fig. 5. The highest power on right rectenna is 
0.00508 watts, which is from right rectenna's output voltage value at $4 \mathrm{~cm}$ distance, while the highest power on left rectenna is 0.00495 watts, which is from left rectenna's output voltage value at $4 \mathrm{~cm}$ distance.

Unlike rectenna's output voltage, the power received by SOMRR's antenna when the radio is on is fluctuating according to the distance, as seen in Fig. 6. The lowest power is $-65.61 \mathrm{dBm}$, which is obtained at the closest distance between rectenna and SOMRR, which is $1 \mathrm{~cm}$, and the highest power is $-60.08 \mathrm{dBm}$, which is obtained at $28 \mathrm{~cm}$ distance.

E. Rectenna's Output Voltage and SOMRR's Received Output Power when the Radio is Off with Distance Variation

Fig. 7 shows rectenna's output voltage when the radio is off according to the distance between rectenna and the radio. The output voltage results do not have significant difference despite the difference in distance.

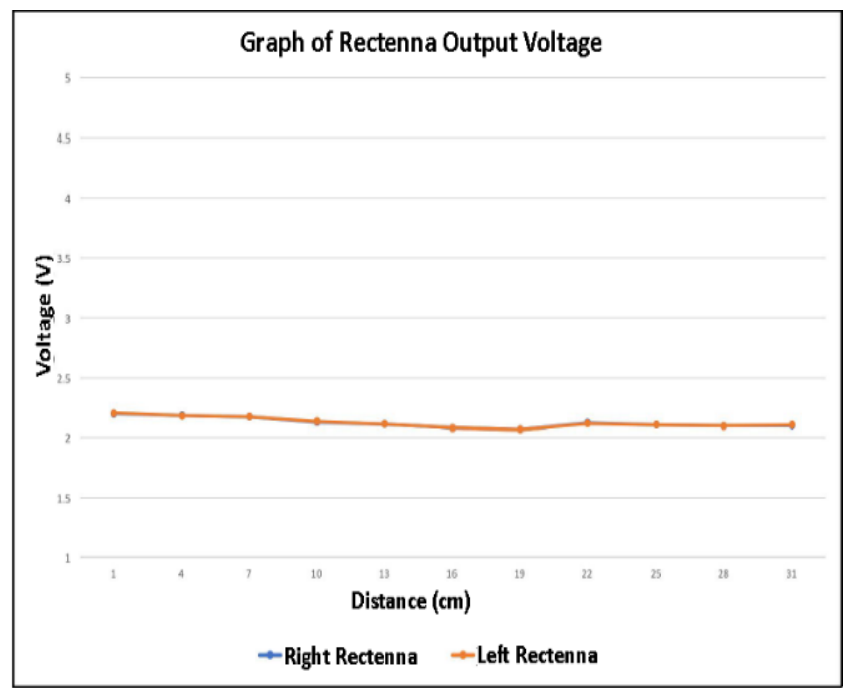

Fig. 7. Rectenna's output voltage when the radio is off.

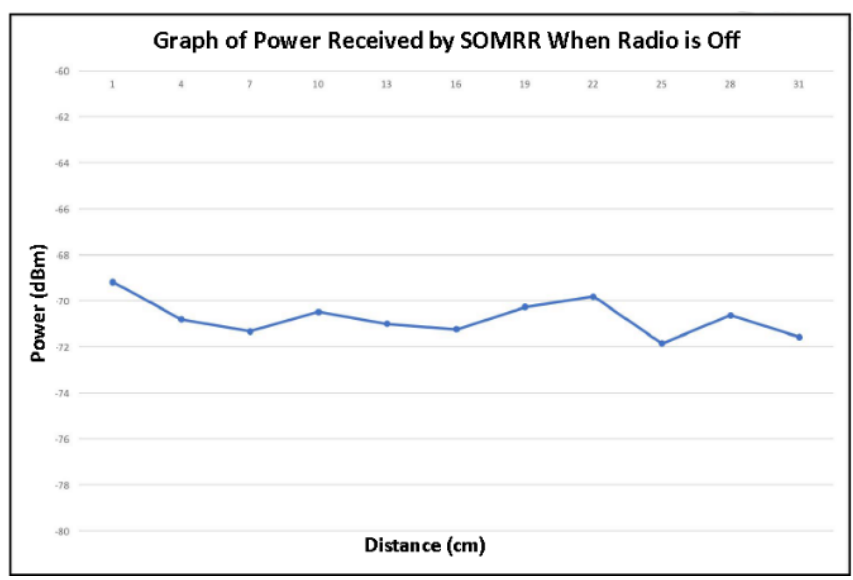

Fig. 8. SOMRR's received power when the radio is off.

Unlike rectenna's output, SOMRR's received power fluctuates along with the increase of the distance between rectenna and the radio. The lowest received power is -71.85 $\mathrm{dBm}$ at $25 \mathrm{~cm}$ distance while the highest is $-69.19 \mathrm{dBm}$ at $1 \mathrm{~cm}$ distance.

\section{CONCLUSION}

From the results, it can be seen that rectenna's output voltage when it is not connected to SOMRR is close to its output voltage when it is connected to SOMRR and the radio is off with the value of $2.201 \mathrm{~V}$ and $2.110 \mathrm{~V}$ respectively while its output voltage is close to zero when it is connected to SOMRR and the radio is on. Therefore, the design of SOMRR using $5 \mathrm{~V}$ relay circuit is proved to be working well.

Rectenna's output voltage value tends to not differ significantly despite the difference in the distance between rectenna and radio no matter when the radio is off or on while SOMRR's received power tends to fluctuate.

\section{ACKNOWLEDGEMENT}

This research is supported by Ministry Research and Higher Education Republic of Indonesia trough PUPTBOPTN 2017 and 2018.

\section{REFERENCES}

[1] C. A. Balanis, Antenna Theory Analysis and Design, USA: Wiley, 2005 .

[2] J. Zhang, Rectennas for Wireless Energy Harvesting, University of Liverpool, 2013.

[3] R. Yuwono and R. Syakura, "2.4 GHz circularly polarized microstrip antenna for RFID application," in Advanced Computer and Communication Engineering Technology, H. A. Sulaiman, et al., Eds. LNEE, Springer, 2015, vol. 315, pp. 37-42.

[4] R. Yuwono, E. B. Purnomowati, and M. H. Afdhalludin, "UB Logoshaped ultra-wideband microstrip antenna," ARPN Journalof Engineering and Applied Sciences, vol. 9, no. 10, pp. 1911-1913, 2014.

[5] Y. Rudy, F. Kumala Trisna, E. Achmad Dahlan, and B. P. Endah Aisah, "Design and construction of egg shaped microstripantenna with circular slot for ultra wideband frequency (UWB) applications," Asian Research Publishing Network. ARPN Journal of Engineering and Applied Sciences, vol. 9, no. 10, pp. 1697-1701, 2014.

[6] P. Bhartia, B. Inder, and R. Garg, Ittipiboon, Microstrip Antenna Design Handbook, USA: Artech House, 2001.

[7] Y. Rudy, I. Mujahadin, and A. Mustofa Aisah, "Rectifier using UFO microstrip antenna as electromagnetic energy harvester," Advanced Science Letters, vol. 21, no. 11, pp. 3439-3443, November 2015.

[8] Y. Rudy, R. Syakura, Y. Purnomowati, and B. Endah. (October 2015). Optimized performance result for $2.4 \mathrm{GHz}$ and $2.45 \mathrm{GHz}$ Circularly polarized microstrip antenna. Advanced Science Letters. [Online]. 21(10). pp. 3007-3008. Available: http://dx.doi.org/10.1166/asl.2015.6435

[9] Y. Rudy, R. Syakura, and D. F. Kurniawan, "Design of the circularly polarized microstrip antenna as radiofrequency identification tag for $2.4 \mathrm{GHz}$ of frequency," Advanced Science Letters, vol. 21, no. 1, pp. 12-14, January 2015.

[10] Y. Rudy and R. Syakura, "Star-L-shaped circularly polarized ultrawideband microstrip antenna for wireless applications," Applied Mechanics and Materials, vol. 548-549, 2014.

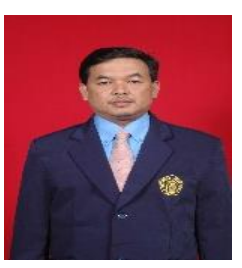

Rudy Yuwono was born in blitar, June 15, 1971. He received bachelot degree from university of Brawijaya, Malang Indonesia in 1997 and master degree from University of Kassel, Germany in 2005. Curently, he is working at Electrical Engineering, University of Brawijaya. Malang as lecturer and researcher. His research interest are antena and propagation, microwave and reasercher. He is with Faculty of Engineering, Departement of Electrical Engineering, Brawijaya University, MT. Haryono st 167 Malang,East Java, Indonesia. 


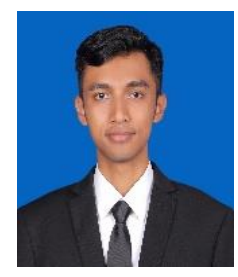

Hilman Yanuar Rahmadi was born in Malang, January 15, 1996. He received bachelor degree in telecommunication engineering from University of Brawijaya, Malang Indonesia in 2018. His research areas include electromagnetics and antenna. $\mathrm{He}$ is with Faculty of Engineering,Departement of Electrical Engineering, Brawijaya University, MT. Haryono st 167 Malang, East Java, Indonesia.

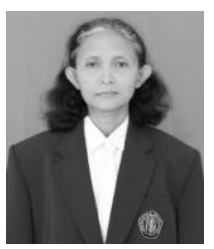

Endah Budi Purnomowati received B.Sc. and M.Sc. from ITS, Surabaya Indonesia in 1982 and 1996 respectively. She is with Electrical Engineering, Brawijaya University Malang. Her areas of interest is mobile communication. She is a reseacher at Telecommunication Laboratory, Electrical Engineering, Brawijaya University Malang. She is with Faculty of Engineering, Departement of Electrical Engineering, Brawijaya University MT. Haryono st 167 Malang, East Java, Indonesia. 